\title{
The Possible Significance of Fructan in Pasture Grass for the Development of Ovine White-Liver Disease (OWLD)
}

Ovine white-liver disease (OWLD) occurs in vitamin $\mathbf{B}_{12}$ deficient lambs in Norway, but not all deficient lambs develop OWLD (Ulvund 1990a). After one month on OWLD pastures, lambs develop sudden hepatolipodystrophy, while no such changes are found in subclinically $B_{12}$ deficient lambs on other pastures (Ulvund 1990b).

The conversion of propionic acid to succinate requires the vitamin $B_{12}$ dependant enzyme methylmalonyl CoA mutase. When sheep are fed diets rich in readily fermentable carbohydrates, they, unlike cattle, synthesize branched-chain and odd numbered fatty acids (BCFA, ONFA) in their tissue, due to an overloading of the methylmalonyl CoA mutase system (Duncan \& Garton 1978). Vitamin $B_{12}$ deficiency in pregnant ewes resulted in enhanced production of ONFA and BCFA in the tissues of their lambs (Garton et al. 1982).

Sutherland et al. (1979) suggested that great intakes of propionate precursors might be significant in OWLD, and Black et al. (1988) proposed that the hepatolipodystrophy might be due to formation of ONFA and BCFA in the liver. MacPherson et al. (1976) and Fell et al. (1985), who obtained OWLDlike changes in experiments on simple Co deficiency, fed a diet rich in readily fermentable carbohydrates.

The amount of water-soluble carbohydrates (WSC) in pasture varies (McGrath 1988). Perennial ryegrass is rich in WSC, the amount is highest in spring-cut grass, and fructan accumulates at an early leafy stage (Beever et al. 1978). Following facts indicate involvement of WSC in OWLD under our circumstances: Perennial ryegrass grows on the OWLD pastures (S pastures), but not on the pastures where lambs get subclinically $B_{12}$ deficient ( $H$ pastures). The development of hepatolipodystrophy coincides in time with lush grass. Calves did not develop illthrift on S pastures (Øverås et al. 1977).

In May 1988, groups of 1 month old lambs with their dams were put on $\mathrm{S}$ and $\mathrm{H}$ pastures (Ulvund \& Pestalozzi 1990a). Half of the $S$ lambs were injected every third week with vitamin $\mathbf{B}_{12}$ (hydroxocobalamin, $2 \mathrm{mg} \mathrm{im}$ ). Blood samples were examined for $\mathrm{B}_{12}\left({ }^{57} \mathrm{Co}\right.$, Radioassay Kit, Becton Dickinson), and grass sampled during week 21,26 and 32 was examined for Co (Ulvund \& Pestalozzi 1990b). Grass sampling for WSC examination was performed weekly during MayJune, then every 2 to 3 weeks. The samples collected and stored by accepted precautions were examined for WSC by the Agricultural University of Norway (As-NLH) with a modified Hulme-Narain's method (Björnson 1962). Reducing carbohydrate (as glucose) and invert carbohydrate (as sucrose) were extracted first by ethanol. The rest (mainly fructan) was extracted with water and hydrolyzed by $\mathrm{HCl}$. Sampling for WSC was repeated the following year (1989), and the fructan content was then looked specificially into, and determined as fructose.

The $S$ lambs and vitamin $B_{12}$-treated lambs grazing the same pastures $\left(\mathrm{SB}_{12}\right)$ were slaughtered on Sept. 5, the $\mathrm{H}$ lambs on Oct. 5. Liver samples from 5 lambs within each group were frozen and later examined by 


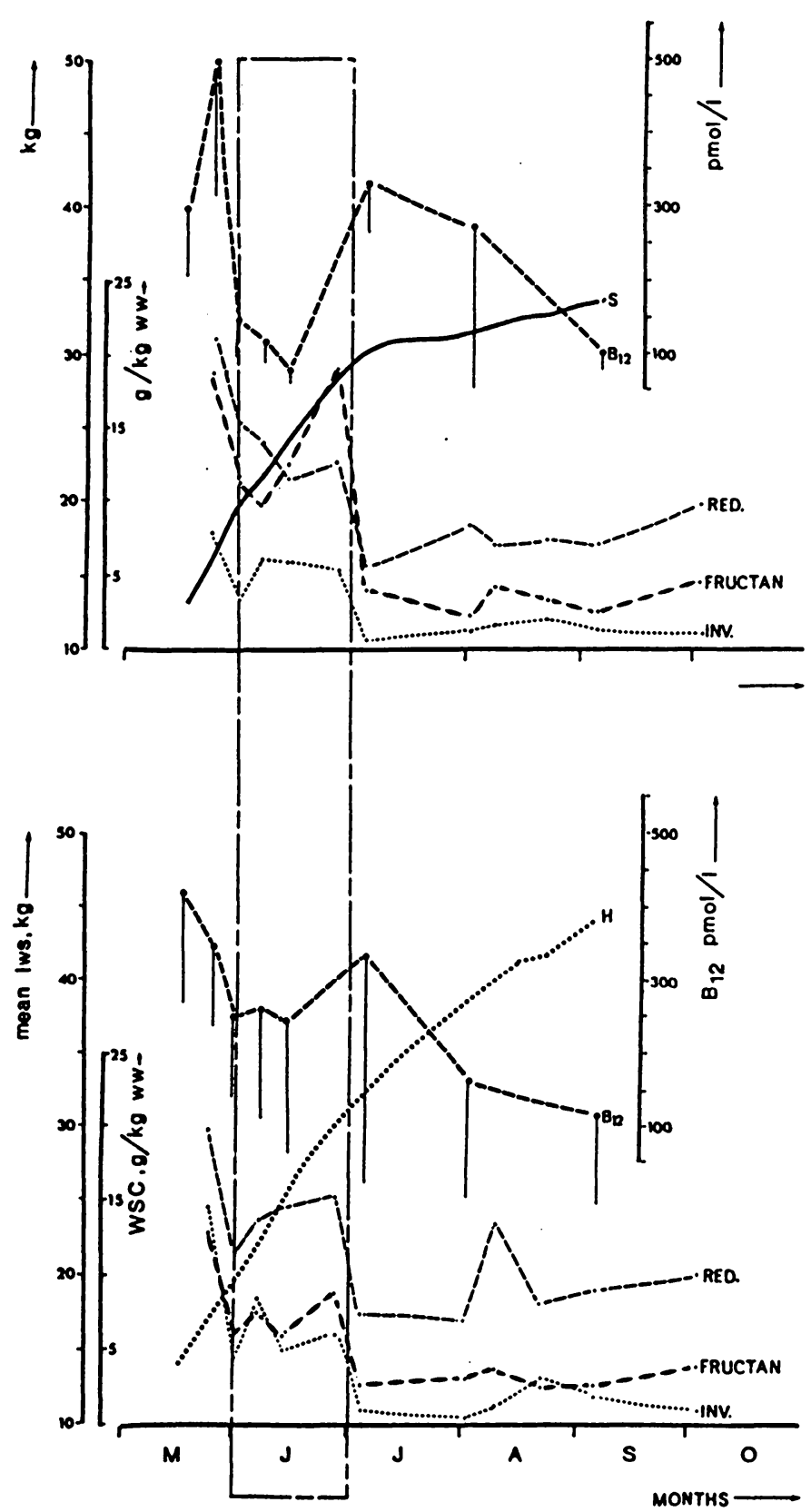

Figure 1. Mean weekly live weights $(\mathrm{kg})$ in 6 untreated lambs grazing OWLD pastures $(\mathrm{S})$ and 24 lambs grazing disease free pastures $(\mathrm{H})$. Mean Plasma vitamin $B_{12}$ values (pmol/l $\pm \mathrm{sd}$ ) in $6 \mathrm{~S}$ lambs and $6 \mathrm{H}$ lambs are also given, as are grass contents of fructan, reducing carbohydrates (RED.) and invert carbohydrates (INV., $\mathrm{g} / \mathrm{kg} \mathrm{ww}$ ). The period of increasing active grazing among the lambs after pasture outlet is shown by a line of demarcation. 
Ås-NLH, for total lipids and fatty acids. Total lipids were extracted in chloroform/ methanol (Folch et al. 1957), fatty acids were estimated according to Welch (1977). Methyl esters were separated by gas chromatography (Dani $8510 \mathrm{GC}$, Flame ionization detector, Chrompack capillary colonne, $\mathrm{CP}$ Sil-5CB, WCOT Fused Silica). Sigma standards were used for identification, and results given as percent of total lipid.

Results are given in Figs. 1 and 2. During the first 5 weeks on pasture, the grass content of fructan was significantly higher in $\mathrm{S}$ grass than in $\mathrm{H}$ grass $(\mathrm{p}<0.05)$. When the lambs were from 6 weeks of age and started to graze actively (June), the fructan content in $S$ grass was $12.9 \mathrm{~g} / \mathrm{kg}$ ww versus 7.3 in the $\mathrm{H}$ grass $(\mathrm{p}<0.05)$. At the same time, the content of reducing and invert carbohydrates was at the same level in both $(18.5 \mathrm{~g} / \mathrm{kg}$ ww in $\mathrm{S}, 19.9$ in $\mathrm{H}$ grass). In 1989, results revealed even greater differences in fructan content during the first 5 weeks $(p<0.025)$, and during June, the fructan content determined as fructose was 4 times higher in $\mathrm{S}$ grass than in $\mathrm{H}$ grass $(9.6 \mathrm{~g} / \mathrm{kg}$ ww versus 2.1).

The $\mathrm{S}$ lambs showed reduced weight gain from early July, while the $\mathrm{H}$ lambs grew well (Fig. 1). By Sept. 5, the $\mathrm{H}$ lambs had on average gained $10 \mathrm{~kg}$ more on pasture than the $\mathrm{S}$ lambs. This year, grass Co was highest on the S pastures. Grass Co $(\mathrm{mg} / \mathrm{kg} \mathrm{dw})$ on the $\mathrm{S}$ and $\mathrm{H}$ pastures respectively was 0.024 and 0.020 during week $21,0.134$ and 0.023 during week 26, and 0.046 and 0.047 during week 32 .

The plasma $B_{12}$ content fluctuated with the grass WSC, especially fructan. This may have implications for the evaluation of reference curves to diagnose cobalt deficiency in lambs. The WSC probably mobilized hepatic $B_{12}$ reserves.

The percentage of total liver lipids was

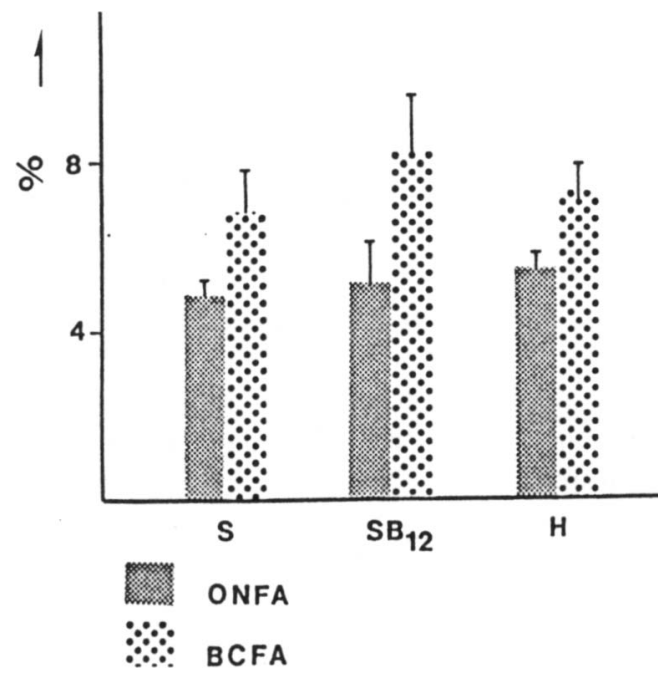

Figure 2. Mean percentages $( \pm s d, n=5)$ of odd-numbered fatty acids (ONFA) and branchedchain fatty acids (BCFA) in total lipids of livers from lambs with OWLD (S), vitamin $B_{12}$ injected lambs grazing the same pastures $\left(\mathrm{SB}_{12}\right)$, and subclinically $B_{12}$ deficient lambs $(\mathrm{H})$.

highest in the $\mathrm{S}$ lambs $(3.06 \pm 1.3)$ as compared with the $\mathrm{SB}_{12}(2.32 \pm 0.1)$ and $\mathrm{H}$ lambs $(2.28 \pm 0.5)$. The percentage of ONFA and BCFA of the total lipids was, however, largely similar in all groups (Fig. 2). The lack of a higher percentage of ONFA and BCFA in the $S$ lambs may be due to very little feed intake during the 2 months preceeding slaughter. The $\mathrm{SB}_{12}$ and $\mathrm{H}$ lambs had good appetite. In addition, access to WSC was poor as grass content was low throughout July-Sept. both years. An effect of "dilution" of ONFA and BCFA by pre-existing fatty acids cannot be excluded. The higher fructan content in OWLD grass in June may have caused an overloading of the methylmalonyl CoA mutase system at that time, and triggered hepatic lipodystrophy leading to hepatic insufficience, growth reduction and OWLD. No such "fructan trigger" appeared on the $\mathrm{H}$ pastures. The results indicate that the amount of fructan in 
pasture grass may be important in the OWLD pathogenesis. Lack of $\mathrm{Cu}$, or a disturbed $\mathrm{Cu} / \mathrm{Mo}$ metabolism, may be a cofactor (Ulvund 1990c). As OWLD may develop in spite of earlier accepted "normal" amounts of $\mathrm{Co}$ in the grass, minimum requirements of $\mathrm{Co}$ for growing lambs on pastures rich in fructan are probably higher than earlier expected. Further experiments are necessary to evaluate the Co requirements in lambs under similar conditions in future.

\section{Acknowledgements}

Senior engineers H. M. Halvorsen ( $\AA$ s-NLH) and M. T. Bjerke, Akvaforsk, are heartfully thanked for examination of grass WSC and liver lipids/ fatty acids respectively.

\section{J. Ulvund,}

State Veterinary Research Station

for Small Ruminants, Sandnes, Norway.

M. Pestalozzi,

State Agricultural Research Station,

Klepp st., Norway.

\section{References}

Beever DE, Terry RA, Cammell SB, Wallace AS: The digestion of spring and autumn harvested perennial ryegrass by sheep. J. agric. Sci. Camb. 1978, 90, 463-470.

Bjornson $O$ : Kvantitativ bestemmelse av monoog dissakkarider, samt inulin i plantemateriale. (Quantitative estimation of mono- and disaccharids and inuline in plant material). Hovedoppgave i kjemi, Ås-NLH, 1962.

Black H, Hutton JB, Sutherland RJ, James MP: White liver disease in goats. N. Z. vet. J. 1988, 36, 15-17.

Duncan WRH, Garton GA: Differences in the portions of branched-chain fatty acids in subcutaneous triacyl-glycerols of barley-fed ruminants. Brit. J. Nutr. 1978, 40, 29-33.

Fell BF, Hesketh JE, Lough AK, Duncan WRH, Mackie WS: Observations on the central nervous system of sheep deficient in cobalt (Vitamin $\mathrm{B}_{12}$ ). In: Mills CG, Bremner I, Chesters $J K$ (eds.): Trace Elements in Man and Animals, TEMA-5. Proceedings 5th. International
Symposium on Trace Elements in Man and Animals, Aberdeen 1984. CAB, London 1985, p. 263-265.

Folch J, Lees M, Sloane Stanley GH: Simple method for the isolation and purification of total lipids from animal tissues. J. biol. Chem. 1957, 226, 497-507.

Garton GA, Duncan WRH, Fell BF: Aspects of cobalt deficiency in ewes and their lambs. In: Gawthorne JM, Howell JMcC, White L (eds.): Trace element metabolism in man and animals. Springer-Verlag, Berlin 1982, p. 382-384.

MacPherson A, Moon FE, Voss RC: Biochemical aspects of cobalt deficiency in sheep with special reference to vitamin status and a possible involvement in the aetiology of cerebral necrosis. Brit. vet. J. 1976, 132, 294-308.

McGrath D: Seasonal variation in the water-soluble carbohydrates of perennial and Italian ryegrass under cutting conditions. Irish $\mathrm{J}$. Agric. Res. 1988, 27, 131-139.

Sutherland RJ, Cordes DO, Carthew GC: Ovine white liver disease - an hepatic dysfunction associated with vitamin $B_{12}$ deficiency. N. Z. vet. J. 1979, 27, 227-232.

Ulvund MJ: Ovine white-liver disease (OWLD). Vitamin $B_{12}$ and methyl malonic acid (MMA) estimations in blood. Acta vet. scand. 1990a, 31, 267-275.

Ulvund MJ: Ovine white-liver disease (OWLD). Pathology. Acta vet. scand. 1990b, 31, 309324.

Ulvund MJ: Ovine white-liver disease (OWLD). Serum effects of copper and selenium supplementation. Acta vet. scand. 1990c, 31, 287295.

Ulvund MJ, Pestalozzi M: Ovine white-liver disease (OWLD) in Norway. Clinical symptoms and preventive measures. Acta vet. scand. 1990a, 31, 53-62.

Ulvund MJ, Pestalozzi M: Ovine white-liver disease (OWLD). Botanical and chemical composition of pasture grass. Acta vet. scand. 1990b, 31, 257-265.

Welch $R W$ : A micro-method for the estimation of oil content and composition in seed crops. J. Sci. Food. Agric. 1977, 28, 635-638.

Øverås J, Pestalozzi M, Helle $O$, Nedkvitne JJ, Matre T: Mixed grazing research in Norway. 28th Ann. Meet. Europ. Ass. Anim. Prod. Brussels, Belgium Aug. 22-25, 1977.

(Received May 4, 1990; accepted May 22, 1990).

Reprints may be requested from: Martha J. Ulvund, State Veterinary Research Station for Small Ruminants, Høyland, P. O. Box 264, N-4301 Sandnes, Norway. 